\title{
A Few Reflections on the Reasons Why Cooperative Firms Have Failed to Gain a Firm Foothold
}

\author{
Bruno Jossa* \\ Università "Federico II" of Naples, Naples, Italy \\ Email: bruiossa@unina.it
}

Received 8 May 2015; accepted 30 June 2015; published 3 July 2015

Copyright (C) 2015 by author and Scientific Research Publishing Inc.

This work is licensed under the Creative Commons Attribution International License (CC BY).

http://creativecommons.org/licenses/by/4.0/

(c) (i) Open Access

\begin{abstract}
After the inception of the cooperative movement in the mid-19th century, it was widely held that capitalistic businesses would soon be replaced by a system of worker-controlled firms and a wealth of policy proposals called for a major impulse to cooperation in later years also. But cooperation has not met with the hoped-for success. How do we account for this? To our day, employee management specialists have been unable to provide a satisfactory explanation for the fact that the policy proposal to introduce democratic firm control still carries little consensus despite the collapse of the Soviet model of communism. In this paper, we give some answers to the question and emphasise the idea that progress in the direction of a generalised system of cooperative firms would amount to a considerable improvement over capitalism, but will hardly be made without the effective contribution of intellectuals and political parties.
\end{abstract}

\section{Keywords}

Producer Cooperatives, Socialism, Mode of Production, Democracy, Darwinism

\section{Introduction}

After the inception of the cooperative movement in the mid- $19^{\text {th }}$ century, it was widely held that capitalistic businesses would soon be replaced by a system of worker-controlled firms and a wealth of policy proposals called for a major impulse to cooperation in later years also (see, for instance, Oakeshott, 1978 [1]; Cornforth et al., 1988 [2]; Ellerman, 1990 [3], Chap. 7; Bardhan \& Roemer, 1993 [4]). Notwithstanding this, cooperation has not met with the hoped-for success. How do we account for this?

To this day, employee management specialists have been unable to provide a satisfactory explanation for the *Retired full professor of political economy. 
fact that the policy proposal to introduce democratic firm control still carries little consensus despite the collapse of the Soviet model of communism. In other words, it is difficult to understand why democratic firm management- the new mode of production which in our estimation is most likely to supplant capitalism today (see Jossa 2005 [5] and Jossa 2012 [6]) —is still receiving little attention and why few scholars anticipate its final success. As mentioned above, things stood differently on the onset of the cooperative movement: shortly after the establishment of the Rochdale Society of Equitable Pioneers (which was rated as the true prototype of the modern cooperative), John Stuart Mill went so far as to argue that the form of association which would eventually prevail was "not that which can exist between a capitalist as chief, and work-people without a voice in the management, but the association of the labourers themselves on terms of equality, collectively owning the capital with which they carry on their operations, and working under managers elected and removable by themselves" (see Mill 1871 [7], pp. 720 and 723). A comparable view was implicit in Marshall's argument that no serious obstacles stood in the way of the ultimate assertion of the cooperative movement, and that this was consequently only a question of time ${ }^{1}$.

Two different, though closely linked issues acquire relevance in this connection: a) the reason why cooperatives have failed to supplant capitalistic companies by degrees; b) the true rationale behind the lukewarm support of cooperation by economists and, generally, intellectuals. As it is clear that worker control of firms would mark a huge leap forward in the direction of economic democracy, an obvious complement of political democracy, in the light of the numerous advantages of democratic firm control discussed in the economic literature ${ }^{2}$, it comes as a surprise that few economists specialising in employee management have suggested the introduction of worker control on a large scale ${ }^{3}$.

Walras, who was a socialist, did not believe that cooperation would bring about a socialist order. In 1900, he wrote (Walras 1990 [8], vol. IX, p. 66): "To look for the social reform in the cooperative association is exactly as to identify it with the mutual assurance. It is at the same time to fail to appreciate the social reform and to magnify the cooperative assurance."

In the opinion of some, today the situation has changed. In the words of Gibson and Graham, "once it was the vision of socialism or communism and the experiments of the soviets in the Eastern Bloc that configured the foreground of the Left's economic imaginary. Today, at least for some, it is the original 'third way' communitarianism or a revitalized social democracy that occupies this otherwise vacated space" (see Gibson \& Graham 2003 [9], mimeo). Yet, the question remains: why have cooperatives failed to become the new polar star for the Left?

\section{Reflections on Social Darwinism}

In all probability, the answer to the second of these queries is that today, more than ever, economists tend to assume that anything of benefit to the community is sure to come about as a matter of course at some point in time and that anything failing to assert itself unaided can barely be advantageous for society as a whole. Quite naturally, this is the belief of liberalists and advocates of what is known as "Social Darwinism" (see, inter alia, Nozick 1974 [10], pp. 314-317; Jensen \& Meckling 1979 [11]; Williamson 1985 [12], pp. 265-268 and Mandel 1973 [13]) or of authors such as Hansmann, who analyse the evolution of society by reference to the "survivorship test" (see Hansmann 1996 [21]); but an attenuated version of this optimistic view is largely shared even by economists who do not rate themselves as liberalists ${ }^{4}$. This is why we think it appropriate to give due consideration to the arguments of those economists who think that democratic firm control is unlikely to assert itself in its

\footnotetext{
${ }^{1}$ Some scholars (including Mandel 1973 [13], p. 349) hold that labour management will make headway in history at the same pace that manual labour loses importance and workers acquire greater educational and professional qualifications.

${ }^{2}$ A dozen advantages of cooperatives over capitalistic firms are highlighted in Vanek 1969 [14] and Vanek 1970 [15]. Horvat’s 1975 [16] analysis (pp. 77-78) covers eight such advantages. The author has dealt with this subject in Jossa \& Cuomo 1977 [17], chaps 6 and 13, Jossa 2010a [18] and Jossa 2010b [19], part I.

${ }^{3}$ The Poor Man's Guardian (Sept. 1833) reported that the delegates from all over the country that had been convened for a meeting of the First International had conceived the aim, "the sublimest that can be conceived-to establish for the productive classes a complete domination over the fruits of their own industry" (Cole 1953 [20], p. 91). but following the advent of Marxism, socialism ceased being identified with worker control of firms.

${ }^{4}$ This was the line of reasoning behind Vergagnini's statement (back in the 1920s) that cooperation could only be the natural outcome of the free play of social forces. Concordantly, several years later a specialist on employee management argued that firms entirely managed by their employees would make headway in markets as soon as their benefits, as perceived by workers, exceeded the corresponding costs, and that no legal barriers actually stood in the way of their establishment (see Putterman 1990 [26], p. 161). See, also, Jensen \& Meckling 1979 [11], pp. 472-473 and Horvat 2000 [27], p. 6).
} 
own right despite its considerable potential for adding to the well-being of the community at large ${ }^{5}$.

A cursory analysis of "Social Darwinism" will serve as a suitable introduction to our line of reasoning.

The extension of Darwinism to economics is a working hypothesis of Veblen and most evolutionary theorists (see, inter alia, Hamilton 1999 [22], pp. 25-28 and Hodgson 2003 [23]); but the idea of a cumulative causation process constantly at work in social life (the specific methodological point of Darwinism that Veblen tends to emphasise) cannot be accepted without reserve ${ }^{6}$. Although we reject Darwin's rejection of a teleological view of history (see, for example, De Gregory 2003 [24], pp. 19-20), we do not feel we can subscribe to Veblen's claim that modern science theorises a process where causes and effects, far from being observed separately in their own right, are, as it were, the links of a chain consisting of an uninterrupted sequence of cumulative changes. on other words, we cannot accept the idea that in every scientific branch research is conducted as a process or active sequence, in terms that each finding is used as the starting point for the next step, in a cumulative sequence (Veblen 1964 [25], p. 40).

In economic theory, a cumulative causation process is often envisaged as a possibility, but it is never thought of as a general rule and is less pervasive than Myrdal \& Kaldor's. The core assumption behind economic theory today is the notion that the economic process tends to move towards stability-the exact opposite of cumulative causation $^{7}$; and while it is true that the relevance of circular causation phenomena should not be underrated, we do hold that the equilibrium view—rather than the cumulative causation notion—is the correct interpretative approach to economic phenomena ${ }^{8}$.

The extension of the natural selection notion to economic processes is objectionable for methodological reasons also, i.e. because of the markedly positivistic rationale it entails. From Gramsci's (as well as Benedetto Croce's) perspective, this is a shortcoming of sociology at large. In Gramsci's words,

"Sociology represented an attempt to create a method for subordinating historical-political science to an existing philosophical system, namely evolutionistic positivism ... an effort to describe and classify historical and political facts in accordance with the logic of natural sciences” (Gramsci 1964 [31], p. 125).

Critics of the idea that economic phenomena are governed by a natural selection process include J. R. Commons, who describes economic phenomena as the result of an artificially induced, not natural selection process (see Commons 1924 [32], pp. 376 and 1934 [33], pp. 636 and 657-658). On this point, several authors have rightly objected that Darwin, far from ruling out a measure of intentionality in the selection process, made it clear that any intentions, where assumed, had to be explained (see Copeland 1931 [34] and 1936 [35], pp. 343344 and Hodgson 2003 [23], p. 91). Hence, Commons's criticism of Social Darwinism can be rated as absolutely cogent. The underlying rationale is the belief that socio-economic and biological evolution are governed by antithetical mechanisms (Hodgson 2003 [23], p. 86) ${ }^{9}$. Whereas evolution determines the success of the strongest in either case (and in economic selection processes the strongest are usually the most efficient ones), economic events are strongly conditioned by an additional factor, namely the power issue. Further on, we will show that organised forces are in a position to inhibit the progress of any firm, however efficient ${ }^{10}$. In the above wording, this objection is not aimed at Darwinism as such—-the principle of the survival of the fittest—but at a particular version of Social Darwinism which equates economic power with efficiency and assumes that the

\footnotetext{
${ }^{5}$ The unaided progress of self-management is implicitly anticipated in the suggestion that knowledge and education, by making people aware of their rights, will help them find means of organising themselves autonomously and that a gradual decline of hired work lies in the nature of things (see Hodgson 1999 [28]).

${ }^{6}$ Many authors have remarked that Veblen himself (at various points in his writings) and several other institutionalists base their analyses on cumulative causation processes (among them, see Miller 2003 [29], pp. 54-55 and Hodgson 2003 [23], pp. 87-90).

${ }^{7}$ In Hamilton's well-known 1953 book, cumulative causation and equilibrium are described as antithetical principles (see Dugger 2003 [30], pp. 65-66).

${ }^{8}$ In fact, most institutionalists hold that the neo-classical approach to equilibrium is to be rejected (see, for example, Miller 2002 [36], p. 252 and 2003 [29], p. 52).

${ }^{9}$ Marx, who was otherwise a great admirer of Darwin, denied the relevance of the Darwinian logic in areas such as history and politics.

${ }^{10}$ Authors critical of Social Darwinism include Bowles and Gintis. According to them, this argument misses the point since it fails to draw a distinction between economic-financial performance on the one hand and efficiency on the other. In competitive markets - they write (1986 [37], p. 84) - survival is a function of profit, which should not be mistaken for efficiency. The distinction between profit and efficiency, they add, will be clearly recognized if we bear in mind that—assuming equal pay rates—profit is determined both by the output per labour unit generated in one hour of work and by the amount of work performed in one hour. And while it is true that the productivity level of the work performed is a good measure of efficiency, they conclude, the amount of work accomplished in a single hour is mainly an indicator of the employer's ability to put in place effective control procedures. Accordingly, if the workers of a cooperative should outperform their capitalistic competitors in terms of streamlining production processes much more effectively, they would attain higher efficiency levels even though they should resolve to work at a slower pace and put up with lesser profits.
} 
most efficient economic organisations are those that will inevitably prevail in the long run.

At any rate, there is good ground for arguing that economic selection mechanisms differ sharply from those governing natural selection ${ }^{11}$. To say that the strongest tend to prevail is just a tautology and, as such, will add hardly anything to our understanding. Things would stand differently if it were possible to say, as social Darwinists mistakenly do, that the best financial performers are also the best organisations ${ }^{12}$.

Let us add that the strongest (and simplest) argument against social Darwinism is the presence of evil and violence in the world and in human behaviour. With reference to cooperatives, Vanek wrote (1978 [38], p. 19) that denying the viability of workers' cooperatives on account of their relative paucity would be tantamount to denying the vitality of healthy tissues in a cancerous body and looking upon the fast-spreading metastasis process as something to be proud of.

Hence, Darwinism is not applicable to economic science for three reasons: a) because the circular causation principle is at odds with the equilibrium principle (so that anyone rating the latter as a cornerstone of economic science must necessarily reject the Darwinian rationale); b) because economic and biological evolution obey different mechanisms; and c) on account of the existence of evil in human society ${ }^{13}$.

In the next sections we will discuss even more specific arguments against Social Darwinism.

\section{Ideas, Interests and Unaided Growth}

The belief that anything benefiting the community will come about unaided and that whatever deserves to make headway should be left to do so through natural or cultural selection is a corollary of the axiom that individual behaviour is rational and of neoclassical economic theorems postulating that those allowed to see to their personal interests will ultimately help maximise the community's well-being. An additional core notion behind rational action theory is that markets can do without institutions. Indeed, the argument runs, whenever a step towards increasing the community's well-being is dependent on institutional changes, it will be taken on condition that there is a political majority prepared to vote for such changes. It is on this particular point that conflict is strongest: on the one hand are those who believe that progress is a function of ideas (and that positive ideas will always assert themselves); on the other are those claiming that the rise of institutions working towards the social good is impeded by vested interests. As is well known, liberalists believe in the power of ideas and tend to assume that mass propaganda will not spark off any appreciable political breakthroughs unless it succeeds in achieving its primary aim—persuading intellectuals (see, inter alia, Hayek 1983 [43], pp. 192-3) ${ }^{14}$. At the other end of the spectrum are Marxists, who denounce the noxious power of vested interests ${ }^{15}$.

Hence we have to ask ourselves if the establishment of democratic firm control is actually hampered by specific vested interests or ideologically biased assumptions.

The ruling classes and high-income individuals all over the world are the stoutest enemies of democratic firm control. As the prevailing circumstances play into their hands, they are inimical to change; and as they look upon economic democracy as a revolution designed to assert equality, they oppose any schemes for the establishment of a different social order.

As mentioned above, liberalists reject economic democracy because of their confidence in spontaneous evolution and uncritical acceptance of the idea that whatever is good and viable will come about as a matter of course. On the assumption of the superiority of capitalism, they are averse to the very idea of revolution (even to a democratic one implemented through a parliamentary vote).

A less obvious finding is that enemies of democratic firm control include trade unions, most of which are ill-disposed towards allowing workers to rum firms on their own. The rationale behind their attitude is the risk

\footnotetext{
${ }^{11}$ In Hayek' estimation, neither biological nor cultural evolution is governed by the laws of necessity, but cultural evolution, which is not genetically determined, generates diversity rather than uniformity (see Hayek 1982 [39], pp. 35-37 and Leube 1988 [40]).

${ }^{12}$ For an interesting analysis of Darwinism and economic evolution, see Colombatto 2002 [41].

${ }^{13}$ The second of the above criticisms of Social Darwinism is likely to be endorsed by those who think (with Nietzsche) that unlike economic systems which are governed by enduring laws, nature is "not a cosmos, i.e. it is not a harmoniously ordered whole whose structure evolves consistently with finalistic aims; it is chaos, i.e. a temporal continuum without any enduring structures or laws and ordained by no intentions (D’Iorio 2013 [42], p. 15)

${ }^{14}$ Nevertheless, even Hayek was compelled to admit that most rules had been fleshed out by reference to the views and interests of one class, so that positive ideas were often prevented from asserting themselves in their own right (see Hayek 1982 [39], p. 115).

${ }^{15}$ Schumpeter, one of those who placed no trust in the power of ideas, wrote (1954 [48], p. 140): "Political criticism cannot be met effectively by rational argument. From the fact that the criticism of the capitalist order proceeds from a critical attitude of mind, i.e., from an attitude which spurns allegiance to extra-rational values, it does not follow that rational refutation will be accepted. Such refutation may tear the rational part of attack but can never reach the extra-rational driving power that always lurks behind it.”
} 
that economic democracy should make workers "their own masters" and allow them to do without the services of organisations for the protection of workers. Economic democracy would sweep away class divisions and the traditional confrontation between associations of employers and unions of workers defending the interests of their respective members. These reflections are, in themselves, enough to explain why trade unions are inimical to such a prospect (see Moene \& Wallerstein 1993 [44], pp. 148-149, Kester \& Pinaud 1996 [45] and George 1997 [46], pp. 59-60) ${ }^{16}$.

Quite appropriately, Raniero Panzieri wrote (1960 [47], p. 116):

"Taking roots within and outside the factory is not a question of distributing tasks and existing (union) officials more effectively. The decisive factor is an innovation process sparked off right within the factory at the cost of calling into question the role, and even the very existence of trade unions. Only a trade union organisation boldly offering collaboration in this direction is likely to play a major role in a true innovation process."

Many authors hold that trade unionists oppose democratic firm control on the assumption that their members are not prepared to take business risks. Palmiro Togliatti, for instance, wrote that industrialists tend to be less inimical to economic democracy than workers. When Italian businessmen announce their intention to turn capitalistic businesses into cooperatives-he claimed-their true design is to turn the current shareholders into creditors of the cooperative firms. This done, they will stop running the production, marketing and other business of those firms and, without sparing a thought for the fate of the industrial sector as a whole, will be satisfied with cashing the fixed interest accruing on their claims (Togliatti 1920 [50], p. 183). Others have argued thatfar from making workers free-industrial democracy would produce the awkward effect of obliging them to adopt the uncongenial rationale of capitalistic businessmen committed to maximising their profits (Tornquist 1973 [51], p. 393).

The idea that workers do not wish to become "their own masters" is widely shared. In point of fact, to establish if this is true workers should be polled following awareness-building programmes illustrating the latest findings on modern economic theory — and as far as we know this has never been done. As mentioned by Hansmann (1996 [21], p. 45), empirical observation has shown that corporate governance researchers tend to overrate the role of risk-takers in the day-to-day running of firms.

Moreover, those workers who do declare themselves hostile to democratic firm control are doubtless influenced by trade union officials, i.e. by those whom they hold to represent their interests.

One reason behind the lukewarm support of cooperation by the Left is the fear that the rise of two organisations for the protection of worker interests might result in a split within the working class. This is what the historian Gaetano Salvemini suggested in the years when Italy was ruled by Cabinets presided over by Giolitti. As the cooperative movement had gained a firm foothold in central and northern Italy, but not in the South (much like today), he argued that its leaders were actively securing government contracts in the exclusive interests of northern versus southern workers and that this strategy had been chosen to please Giolitti (see Salvemini 1993 [52], pp. 356-358 and 359-383).

To account for the half-hearted support of trade unions (rather than opposition proper), Braverman points to issues such as technological progress and labour productivity. "The unionized working class—-he writes (1974 [53], p. 10) -intimidated by the size and complexity of capitalistic production, and weakened in its original revolutionary impetus by the gains afforded by the rapid increase in productivity, increasingly lost the will and ambition to wrest control of production from capitalistic hands and turned ever more to bargaining over labor's share in the product. This labor movement formed the immediate environment of Marxism; and Marxists were, in varying degrees, compelled to adapt themselves to it”.

Lastly, democratic firm management is opposed by the traditional Left, especially by Marxists, due to the fear that the market economy in which an all-cooperatives system is intended to operate would envisage far less state intervention in the economy than there is today (see, inter alia, Adler-Karlsson 1986 [54], pp. 46-47). Indeed, the propelling force which might correct the dysfunctions of the system and drive on a market economy is democratic firm management, rather than state intervention. Considering that workers in an economic demo- cracy are held to become "their own capitalists" (Dubravcic 1970 [55]), there is ground for arguing that cooperation would help workers acquire a role which used to be monopolised by capitalistic businessmen and corporate governance executives. Hence, the scant concern of some Leftist groups with economic democracy arises in connection with three main reasons: a mistrust of markets, statist leanings and a traditional aversion to entrepre-

\footnotetext{
${ }^{16}$ Perry Anderson argued that unions represent the the interest of labourers within capitalism and, therefore, are unable to challenge the contradictory relations between capital and labour in the world in which we live (Anderson, 1967 [49], pp. 264-68).
} 
neurs (though this seems to be a thing of the past) ${ }^{17}$. In 1888 [56], Gide (p. 66) suggested that the distance between workers' parties and cooperative ideals was to be traced to a more than centennial influence of socialist, specifically collectivist ideas.

As Gide himself acknowledges further on in his essay (1988 [56], p. 68), this finding may strike us as surprising since socialism and cooperation claim descent from Robert Owen in Britain and Charles Fourier in France and are consequently akin by origin ${ }^{18}$.

Concluding this section, let us mention that our approach is disclaimed by numerous authors who think that the role of ideology in hampering the growth of the cooperative movement has been at most tangential (see, inter alia, Hansmann 1996 [21], pp. 87-88).

\section{Corporate Governance and Economic Democracy}

Numerous other forces, besides antithetical ideologies and interests, stand in the way of the transition—albeit slow and gradual-from capitalism to economic democracy.

Firstly, today economic activity is conducted within a legal framework which is structured in such a way as to favour the growth of capitalism and extend it in time. This is a basic tenet of Marxist thought, which distinguishes between the economic base and the superstructure, i.e. the economic structure of society versus its legal, political and other aspects, and assumes the latter to be conditioned by the former ${ }^{19}$. In fact, this view is also shared by a large number of non-Marxist economists. There is little denying that laws and institutions which play into the hands of capitalistic businesses are antithetical to those that would expedite the growth of democratic firms. Over the centuries, the laws and institutions of capitalistic society have been fleshed out in manners conducive to the creation of an environment consistent with its requirements, and the main beneficiaries of this state of affairs are doubtless capitalistic businesses, rather than democratic firms ${ }^{20}$. Several authors (see Putterman 1984 [59]; Hodgson 1993 [60], pp. 91-93; and Gunn 2000 [61], pp. 451-455) have argued that within a different context, with different institutions, democratic firms would probably outnumber capitalistic businesses. In other words, in accordance with a typical hysteresis process the economic growth pattern of the past ensures that those systems that have gained the upper hand for whatever reason will generate institutions and an environment that will help them trounce competition from others (see Arthur 1989 [62], North 1990 [63] and Pagano 1991a [64] and 1991b [65]) $)^{21}$. In the opinion of Vanek (1971 [66], p. 171), producer cooperatives and other democratic firm types fail to gain a firm foothold since they operate within an extraneous environment.

From the perspective of a well-known law expert, throughout this century, the legislatures have been pursuing a clever design: instead of repressing the cooperative movement, they have manoeuvred to "sabotage" it from within, i.e. they have introduced the capitalistic logic of profit into cooperatives in an attempt to win over their members to this logic (Galgano 1974 [67], p. 163).

In point of fact, this argument is rated as fairly negligible by other authors (including Hansmann 1996 [21], pp. 85-86).

One aspect of this issue is the theory that traces firm control to the specificity of its resources and emphasises the tendency of economic systems to self-perpetuate them selves. The theorists concerned hold that business firms arise when a group of producers uses team-specific resources, i.e. resources which would suffer a decline in value if they were moved to a different team. From this basic idea, it follows that control will usually be vested in the most significant firm-specific factor. In capitalistic systems, this factor is usually capital. At this point, one may wonder if-in a vicious circle of sorts—-there is a mechanism capable of determining that just as capitalistic firms are mainly connoted by capital, so democratic firms would be mainly connoted by labour.

It is well known that ownership titles vest in the owners of goods the right to prohibit others from using such goods, and although it is inappropriate to use the term ownership title when speaking of a business enterprise (see Ellerman 1990 [3] and 1992 [71]), it is possible that the factor resolving to take over the control of a firm

\footnotetext{
${ }^{17}$ From a socialist perspective, Antonio Labriola criticised cooperation as an illusory, even deceitful solution (see Labriola 1970 [57], pp. 271-272).

${ }^{18}$ Fabbri also (see Fabbri 1981 [58], p. 829) described cooperation as the "brother german" of trade unions.

${ }^{19}$ In German Ideology and elsewhere, Marx ed Engels wrote that the ideas of the ruling class are in every epoch the ruling ideas, i.e. that the class which is the ruling material force of society is at the same time is ruling intellectual force (see Marx \& Engels 1845-1846 [68], pp. 35-36).

${ }^{20}$ In this connection, Perotin has argued (2006 [69], p. 299) that “as the number of organizations of a given form grows, the form is regarded as more legitimate and this legitimacy in turn results in more organizations of the same king being created."

${ }^{21}$ With regard to the conservative nature of institutions, see, also, Veblen 1899 [70], pp. 190-198.
} 
may do so in an effort to avoid being ousted from it. Thanks to the awareness that they cannot be ousted, those in control of firms will probably increase their investments in "human capital" and this will further increase the specificity of the firms they control.

In other words, the relationship between the ownership title in resources and the specifics of such resources can be said to evolve in either direction. Marx held relations of production and ownership rights to be determined by the level of growth of the productive forces, but he also emphasised the opposite causal link when he demonstrated that the effect of capitalistic ownership relationships is to multiply obsessively repetitious jobs that can do without specialised skills.

A causality link between ownership rights and the characteristics of the resources used has recently been emphasised by some radical economists who have reversed the links highlighted by neoinstitutionalists. From the starting assumption that control is either vested in firm-specific resources or in resources that are difficult to monitor, they have deduced that most of the workers employed in capitalistic businesses are both "easily monitored" and "non-firm-specific" since the owners of such businesses select them with this end in mind and will barely think of adding to the qualifications of workers not bound to their firms by permanent ties. As is well known, an investor in human capital is not entitled to cash the (future) earnings of the individuals concerned. Consequently, a firm investing in staff qualification programmes is at risk of wasting the relevant expenditure due to the fact that nothing can prevent its workers from leaving the firm upon completing their training programme. In other words, from the perspective of radical theorists, difficult control of resources and their greater or lesser specificity are the effects, not the cause, of the existing structure of property rights.

In even more general terms, it is possible to argue that growth obeys the same mechanism in democratic and capitalistic businesses: conditions favourable to their growth are more likely to arise in situations where firms of the category concerned outnumber other forms of business enterprise (see Bowles \& Gintis 1993 [72], p. 31).

\section{The Costs of Democracy}

It is a fact that the costs entailed in the exercise of democracy are an additional explanation for the limited success of the cooperative movement. Discussing the costs of democracy as a drag on the assertion of cooperation, in a well-known monograph Hansmann remarks that such costs: a) are low in capitalistic businesses because capital holders consistently pursue the same goal—maximising return on capital—and measure their respective inputs by reference to a single parameter - the amount of capital resources contributed by each of them; b) are much higher in self-managed firms, and even more so when their members have different professional qualifications and diverging interests. In Hansmann's estimation, there is a basic issue which has received far too little attention: what might be termed the internal policies of the firm or, in more abstract terms, the costs of collective decision making, has a critical bearing on the patterns of ownership that we observe and the ways in which firms are structured internally (see Hansmann 1996 [21], p. 2); and his conclusion is that the costs of democracy are the primary explanation for the relative paucity of democratic firms.

It is well known that one of the main costs of democracy stems from the fact that a majority and an opposition may engage in a head-on clash. In capitalistic companies, where workers have no decision powers, they only have the option, as it were, to "vote with their feet", i.e. to give up their jobs and leave the firm. As long as they stay, being deprived of decision powers they are "voiceless"; the workers of a capitalistic business have no way out but to stick to their jobs and put up with a systematic disregard for their needs.

At the other end of the spectrum, workers in democratic firms do have "a voice", but may have to endure the bitter experience of being in a minority and having their "voice" silenced by the majority. In such a situation, the minority members may oppose the decisions of a majority which they feel is refusing to listen and abusing its power position. The "costs" of the resulting split in the workforce and rise of two hostile factions may be a head-on confrontation, the refusal of minority workers to collaborate and manoeuvres designed to reverse the resolutions passed ${ }^{22}$. These costs may spike to a tremendous high if-as often happens-a particularly active and able minority group, using to advantage the disinterest of many and a better familiarity with the circumstances of the case, should succeed in imposing its will on the majority.

Additional major costs of democracy include the time and effort required for collective decision-making. To meet the wishes of the greatest possible number of members, the decision-makers will have to determine the preferences of possible participants in an initiative and then proceed to call meetings, exchange opinions and put

\footnotetext{
${ }^{22}$ The smaller the firm, Panebianco (2004 [73], p. 83) argued, the greater the risk that a majority group may coerce a minority group.
} 
alternative options to the vote. As different individuals are known to have different preferences and there is never just one possible option, the more such preferences diverge, the more will decision-making prove difficult and require cyclical polls. Occasionally, during such cyclical decision-making processes some workers may even be tempted to trade votes (see Weingast-Marshall 1988 [74], p. 32 and Hansmann 1996 [21], pp. 41-42).

A way out of this deadlock is delegating decision powers to third parties, for instance committees, and instructing them to analyse a set of options or pass resolutions that will be binding on all the members, but Hansmann warns that power delegation may result in difficult relationships between principals and agents.

An additional cost stems from the egalitarian ideology by which democracy is connoted, especially from the tendency of democratic firms to level out payroll rates and, at times, assign the same pay rate to all the members. Hansmann remarks (see op cit, p. 93) that in some types of firm, for instance cooperative law firms, the individual productivity levels of the members are fairly easy to monitor and hence he finds it stupefying (p. 93) that such a firm should resolve to adopt equal pay policies and thereby renounce the benefits that might flow from the powerful incentive of some members to increase their inputs in an effort to boost their incomes (supra, p. 93). His conclusion is that democratic firms are likely to gain ground only in sectors of activity with fairly similar job descriptions or easily measured productivity levels, for instance among cab drivers ${ }^{23}$.

On the subject of homogeneous job descriptions, Hansmann argues that "the viability of employee ownership is severely compromised when the employees who share ownership play diverse roles within the firm" (see op. cit., p. 92) and concludes that "homogeneity of interest is one of the major factors determining the costs of ownership that a given class of patrons can bear." In his opinion, this is one of the reasons why self-managed firms have failed to gain a firm foothold despite the major efficiency gains they ensure (see op. cit., p. 288).

Hansmann gives credit to the widely held view that egalitarianism is a by-product of collective decision-making. In other words, he holds that distributive inequalities are less pronounced in cooperative firms because the members have equal decision powers (see op. cit., p. 95) and notes that this explanation supports the argument that democratic firms will gain ground only in sectors where the members have roughly the same qualifications and preferences ${ }^{24}$.

The homogeneous-personnel requirement is closely associated with the argument that cooperatives are "weak" firms operating in "weak" markets and may help explain the particularly slow progress of the cooperative movement in the South of Italy. Surveys have shown that the workforces of cooperatives in northern Italy include higher percentages of women-workers than those in southern Italy, while over $60 \%$ of the cooperatives operating in Southern Italy are owned by women (see Battilani \& Bertagnoni 2007 [77], p. 24).

To refute this argument, suffice it to mention that it is based on existing cooperatives and not on the model recommended by economists today. In the author's opinion, the main plus points of cooperation are the disempowerment of capital, a fundamental contribution to political democracy and the suppression of "classical" and "Keynesian" unemployment (see Jossa 2014 [78], chap. VIII), rather than the empowerment of workers. In other words, departing from the traditional model, modern economic theorists think that the powers of the workers' collective should be confined to passing a limited number of resolutions such as electing and revoking managers.

This adjustment to the traditional organisational model should be viewed in combination with an additional one. Inasmuch as it is true-as we think it is - that the model deserving to be prioritised is the medium-large cooperative, it will hardly appear reasonable to vest in workers the power to make important business decisions. These will draw adequate satisfaction from the sovereign rights (albeit confined to appointing and revoking managers) which are vested in them, from the awareness that their jobs are stable and safe and, above all, from the shares of the residual they are entitled to cash.

On several occasions, Luigi Einaudi argued that democracy was detrimental to business performance and that self-managed firms were bound to face serious financing difficulties on account of inefficiences inherent in economic democracy. "Today - he wrote - capital is a submissive, inarticulate servant granted to persons who are deemed to be trustworthy and have made a name for themselves for major organisational skills... In the eyes of capitalists, giving carte blanche to the entrepreneur or tradesman, i.e. to one man, is a prerequisite for the success of any enterprise" (Einaudi 1920 [79], p. 849).

Our main objection to this is that Einaudi did not consider that the members of a cooperative are free to dele-

\footnotetext{
${ }^{23}$ In an essay dated 1998, Hart and Moore provide evidence that cooperatives with homogeneous member preferences may reach first-best equilibrium, whereas business enterprises managed by capitalists may prove inefficient.

${ }^{24}$ Kollock (1998 [75]) and Huberman-Glance (1998 [76]) have remarked that peer monitoring among members, far from being a simple practice, may give rise to paradoxical situations.
} 
gate all their powers to a manager of their choice. In the estimation of Putterman (1990 [26], p. 169), the management and leadership delegation hypothesis entails that decision-making in worker-controlled firms does not necessarily require the involvement of a large number of people; and at any rate, he adds, final decision-makers in worker-controlled firms do not necessarily outnumber the shareholders performing this role in a capitalistic firm such as a limited company (see Putterman 1990 [26], p. 169).

Luigi Einaudi's argument that "able proactive managers will be leaving the enterprise as soon as a workers' council is established" (see Einaudi 1920 [79], p. 688) was later refuted in theoretical contributions published within the framework of the long-drawn debate on Alchian and Demsetz's 1972 paper. Indeed, there is no evidence that managers working in the interests of workers are less efficient than those working in the interests of - mostly absentee-capitalists.

At first sight, the idea that business decision-making powers should be solely vested in managers would appear to nullify the main advantage of a cooperative system, its democratic essence. On closer analysis, instead, democratic governance is doubtless the most significant characteristic of cooperatives, but has nothing to do with empowering the members to run the day-to-day business of their firm. Let us mention that the principal advantages of economic democracy are a) the disempowerment of capital and b) a leap forward in the direction of political democracy with the resulting eradication of plutocracy. This does not mean we endorse the view of the State as the lobbying group of the bourgeois class. It simply means that-given the strong impact of economics on politics-no political system can be rated as fully democratic if it fails to introduce democracy into its economic system ${ }^{25}$.

An additional thorny aspect of democratic firm management is that difficult decision-making may both accelerate the disappearance of cooperatives and the degeneration process that will be discussed below. The most proactive members of a cooperative and those interested in rapid and efficient decision-making may be tempted to gain full control of the firm by ousting the other members one by one.

Concluding this section, let us emphasise that the main advantage of self-management, democratic firm governance, is often rated as its main defect.

\section{Start-Up Problems}

An additional reason why cooperatives have lost out to competition from capitalistic businesses is the obstacles impeding the establishment of cooperatives. Before a cooperative can be established a group of individuals with equal powers will have to come together and reach an agreement covering all the main aspects of a business project. There is little denying that such an agreement is far from easy to reach ${ }^{26}$. The same is not applicable to capitalistic businesses, whose founders are simply required to enter into bilateral agreements, i.e. to conduct negotiations with one person at a time in two-way interviews during which third parties have no voice. In other words, whereas the precondition for the birth of a democratic firm is a multilateral contract unanimously executed by a number of different stakeholders, the capitalistic business enterprise arises following the execution of bilateral contracts through which the instigator secures the collaboration of third parties-and bilateral contracts are much more easy to negotiate.

Some theorists think that the difficulties associated with the execution of multilateral contracts are usually overstated. As a rule, they argue, the model firm is established on the initiative of a single individual and where the firm concerned is intended to become a cooperative, the relevant ownership rights and management functions are apportioned among a plurality of individuals only after the establishment of the firm. Examples of this procedure include a number of forest cooperatives in the Pacific Northwest, which were originally set up by single promoters (see Hansmann 1996 [21], p. 145). On closer analysis, the above objection is not fully overruled by this argument. While it is true that some cooperatives are established on the initiative of single individuals, it

\footnotetext{
${ }^{25}$ In the words of Touraine, the main characteristic of capitalism is the suppression of all social, political and other checks on the actions of economic actors: whenever these are freed from control, they impose their will on all other institutions, in terms that the latter will always have to act in accordance with the interests of those controlling the economy. This power, he adds, is the true cornerstone of capitalism (Touraine 2004 [80]).

${ }^{26}$ In the opinion of Ben-Ner (1987 [81]), one of the causes of the relative paucity of cooperatives is the fact that an able entrepreneur does not deem it in his interests to share the prospective earnings from a newly-founded firm with third parties - as would be the case in a cooperative. In point of fact, the different distribution patterns of cooperatives versus capitalistic businesses arise in connection with a variety of different reasons (see, inter alia, Pérotin 2006 [69]). However, in Pérotin 2006 [69] (p. 296) we also read that the average entry rate for cooperatives in France in the years 1979-2002 was 15\%, i.e. considerably higher than the corresponding average recorded for conventional businesses in the same period (12\%). See, also, Steinherr \& Vanek (1976 [83], p. 340).
} 
remains that businessmen setting up firms will opt for hired personnel in preference to sharing powers with third parties in a cooperative. Consequently, the start-up problems just discussed are an additional explanation for the relatively small number of cooperatives in existence.

The role that start-up difficulties play in impeding the unaided assertion of the cooperative movement is confirmed by the experience that most existing cooperatives were set up by members with comparable qualifications and skills. The model case is the cooperative joining professionals with equal qualifications, for example a law firm. For functions requiring different qualifications, for instance typing or janitoring services, such a firm will preferably opt for hired personnel (see Hansmann 1996 [21], pp. 91-92). And experience in this field seems to support the view that persons with non-homogeneous qualifications and preferences will hardly ever reach the agreement necessary to establish a cooperative firm (see Hart \& Moore 1990 [82]).

The situation is less complex when it comes to changing an existing firm, for example a limited company, into a cooperative. Indeed, in such a case the business structure, organisation chart and payroll arrangements of the pre-existing enterprise can often be transferred to the new firm without any appreciable changes ${ }^{27}$.

\section{Funding Difficulties}

At this point, it is possible to discuss additional obstacles standing in the way of a spontaneous evolution towards economic democracy.

As argued by Meade (1972 [85], p. 426), "while property owners can spread their risks by putting small bits of their property into a large number of concerns, a worker cannot put small bits of his effort into a large number of different jobs. This presumably is the main reason why we find risk-bearing capital hiring labour rather than risk-bearing labour hiring capital."

From this and? the above-mentioned start-up difficulties it follows that a democratic firm will only be established in the absence of a person with sufficient entrepreneurial skills prepared to run it-and this determines that few worker-controlled firms will actually be viable.

The opinion that the main drag on the performance of cooperatives is lack of entrepreneurial skills is also supported by other arguments. Firstly, due to their small size and the egalitarian practice of minimising payroll rate differences, cooperatives fail to offer would-be managers rewards on a par with those offered by capitalistic firms; secondly, as relatively few cooperatives are in existence, most managers are not sufficiently familiar with the specific circumstances under which cooperatives conduct business (see, inter alia, Cornforth 1989 [86], p. 44).

An even more forceful objection was raised by Vanek. According to him, the biggest obstacle to the unaided development of a system of worker-controlled firms in a capitalistic context is probably the so-called "collateral dilemma” (see Vanek 1970 [15], p. 317), i.e. the fact that potential capital providers require the lodging of collateral to back up repayment of their loans and that most workers own no property to use for such purpose. In other words, those owning sizable financial resources tend to invest them in capitalistic companies and propertiless people lack the resources required to give security to potential lenders. This argument also is perfectly in line with the conclusion that the primary obstacle to a spontaneous evolution towards democratic firm management is difficult firm creation ${ }^{28}$.

At any rate, as this is an issue with which cooperators and historians are all too familiar, an in-depth discussion of its implications is probably redundant. For this reason, advocates of cooperation-and Proudhon more forcefully than any others-have been emphasising the need to establish credit institutions with the specific mission of funding cooperatives and granting cooperatives zero-interest loans.

In point of fact, funding difficulties recede in time since a going cooperative owns machinery and equipment which cam be foreclosed and since lenders are aware that the members are unlikely to launch high-risk projects that might jeopardise the income opportunities they have been creating for themselves in years and years of hard work.

\footnotetext{
${ }^{27}$ The democratic essence of the firm may weaken managers in terms of depriving them of authority in their relations with the members by whom they are elected. And this may in turn pose a serious threat to efficiency (see Jensen \& Meckling 1979 [11]). In this connection, Bernstein (1899 [84], p. 159) argued that where the disempowerment of the capitalistic owners, "the true reference point of all corporate governance organs" should not be accompanied by the thorough transformation of the organisation as a whole, it would automatically lead to the prompt dissolution of such organs. For an in-depth analysis of the involvement of the members in decision-making processes and the powers of managers in self-managed firms, see Obradovic \& Dunn 1978 [87].

${ }^{28}$ This argument is discussed in depth by Bowles and Gintis, who take exception to what they term "the asset neutrality proposition" (see Bowles and Gintis 1986 [37], pp. 66-71).
} 
Accordingly, as long as the decision makers of a firm are held liable for their obligations, lending to a cooperative is deemed to be more risky than lending to a comparable capitalistic business.

As far as the specific funding difficulties of the LMFs are concerned, in the latest economic literature they are summed up as follows. As a rule, lenders are particularly well-disposed towards firms which self-finance their investments because they know that the use of self-owned resources is a sign that the firm is confident of success. And this is an additional explanation for the fact that the interest rates charged by external providers of funds tend to increase in an inverse proportion to the self-funded share of a firm's investments. Moreover, in line with Kalecki’s "increasing risk proposition" (see Kalecki 1937 [88]), the risks taken by workers who cash their shares of the firm's residual escalate in proportion to the percentage of the investments that is funded with borrowed resources. As a result, if the self-managed firm is an LMF, a firm which funds its investments exclusively with loan capital, in the event of a failure the risks for the members will be maximised.

As argued by Drèze (1989 [89], chap. IV, and 1993 [90], pp. 257-262), self-managed firms with a fairly high capital-labour ratio and those intending to launch comparatively high-risk projects may find it particularly difficult to obtain credit and will be induced to have recourse to risk capital. In this regard, it is interesting to mention that joint-stock companies were introduced and gained ground in capitalistic systems because they offered means of solving funding problems exactly in these delicate situations. In other words, worker-controlled firms with very high capital-labour ratios and those launching high-risk projects derive most of their earnings from capital, and if the loan capital they use has been borrowed at fixed interest rates and must be remunerated before the residual is determined, in situations of crisis the members' income from work will be greatly eroded, if not altogether nullified.

Several authors have lately raised an issue which may have a distinct bearing on LMFs. Specifically, they have suggested that limited liability companies may find it convenient to adopt an opportunistic conduct, i.e. to use borrowed resources to fund personal needs of the decision-makers or particularly high-risk projects on the assumption that any profits earned would be cashed by the firm, whereas losses, where any, would be solely charged to the account of the providers of the relevant funds (see, inter alia, Putterman, Roemer \& Silvestre 1998 [91], pp. 886-897 and Pittatore \& Turati 2000 [92], p. 27).

\section{The "Degeneration" of the Democratic Firm}

The first theorist who raised the issue of a possible "degeneration" of cooperative firms was Beatrice Webb. The more a cooperative moves ahead, she argued, the more will it tend to "degenerate" into a capitalistic firm, in terms that its members will find it convenient not to share the firm's earnings with other members. Since then, several authors have suggested that the majority members of a cooperative will consider the replacement of minority members with hired workers every time the residual is to be distributed (hired workers have no title to distributions). At that point, they argue, the members left will form a new majority which will once again consider the possibility of ousting minority members and replacing them with hired staff (or, alternatively, depriving them of their voting and participation rights and, hence, changing them into hired employees). As the transformation of the cooperative into a capitalistic business is accelerated by each new hire, there is good ground for arguing that a successful cooperative wishing to increase its workforce will tend to use hired personnel (Webb \& Webb 1921 [93] and 1923 [94]; Ben-Ner 1984 [95] and 1988 [96]; Gunn 2000 [61], pp. 451-55; on the contrary, the "degeneration" process is understated in Hansmann 1996 [21], pp. 81-84).

In our opinion, to read this argument as a criticism of self-management would be a mistake. Its true purpose is to help us emphasise that a democratic firm that is to be run efficiently must not be turned into a mixed business and must consequently abstain from taking on hired personnel. In other words, the prerequisite for the final success of a system of democratic firms is the enforcement of laws which prohibit cooperatives from employing more than a certain percentage of hired personnel ${ }^{29}$.

\section{The Approach of Gregory K. Dow}

The reflections developed so far may help us examine a book-length study in which Gregory K. Dow provides

\footnotetext{
${ }^{29}$ Producer cooperatives tend to take on hired personnel whenever this is not prohibited by law. In this connection, it is interesting to note that C. Gide, one of the most convinced and authoritative $19^{\text {th }}$ century advocates of cooperation, observed that the future of cooperation lay in consumers', rather than producers' cooperatives. The reason for this prediction was that many French cooperatives were employing hired workers and had consequently been turned, in practice, into associations of petty masters using hired personnel working at their orders and for their account (see Gide 1888 [56], p. 101).
} 
his own analysis of the reasons why capitalistic businesses outnumber employee-controlled firms. In Dow's opinion, the critical point is the fact that capital is alienable, while labour can be hired but not purchased by capital, but he admits that while this antithesis is a unifying factor behind some possible explanations for the relative paucity of cooperatives, it is of little help in refuting others.

Upon upgrading its capital goods, he argues, a capitalistic company is well aware they these cannot be appropriated by third parties; in contrast, a cooperative knows all too well that the moment its member-workers develop sophisticated qualifications and skills they may move to other firms prepared to offer more rewarding income opportunities. Secondly, whereas an able entrepreneur who sets up a capitalistic firm or takes over a cooperative can keep for himself all the earnings from a successful business concept developed by him, individuals joining to form a cooperative or take over a capitalistic business will have to share their earnings with others. Thirdly, but most importantly, a high-income capitalist who takes over a firm is free to run its operations as he deems best, whereas the management of a cooperative firm is conditioned by the above-mentioned constraints associated with collective control. In more general terms, while capitalistic businesses are mostly run by a comparatively small number of like-minded directors, the control group of a cooperative is always the workers' collective, i.e. a larger group.

According to Dow, three main factors determine which factor will be taking over control: the sense of purpose that those entitled to take over control are able to develop, the size and heterogeneity of the control group and the existence of a market for control positions; and the differences between capitalistic and worker-controlled firms with respect to these factors are caused by the alienable capital/inalienable labour contrast (see Dow 2003 [97], chap. 11).

On closer analysis, however, Dow's approach is far from convincing. The argument that the progress of self-management is impeded by the contrast between alienable capital and inalienable labour does not add much to our understanding and we also doubt that Dow's approach actually includes elements common to other explanations for the paucity of worker-controlled firms. For example, even assuming that the funding problems of cooperatives are as material as he holds them to be, it remains that they have nothing to do with the alienable capital/inalienable labour antithesis. In actual fact, they are caused by the inability of workers to lodge all such security as is generally given to lenders by capitalists.

In our opinion, an additional reason why his approach is objectionable is his failure to mention the option of delegating decision powers to a manager - an option which effectively refutes the assumption that the control group of a capitalistic business is more efficient since it consists of fewer members. At any rate, its most serious shortcoming is that Dow fails to mention lack of support from intellectuals as a cause of the paucity of cooperatives in existence. In point of fact, the limited scale of the cooperative movement is to be traced to inadequate awareness of the advantages of cooperation and, therefore, to insufficient government incentives. Regardless of the reasons why cooperatives are far from firmly established, there can be little doubt that the moment their nature as merit goods is understood to the full, they will start moving ahead and ultimately fight off the competition of capitalistic businesses.

Dow thinks that cases such as the Mondragon Group in Spain and Italian cooperatives are clear evidence of the importance of an institutional mechanism supporting the establishment of new cooperatives and/or the conversion of capitalistic businesses into employee-controlled firms. Hence, he correctly concludes that governments should enforce suitable laws and financial aid systems to encourage the rise of a large-scale cooperative sector, but erroneously adds (op. cit., p. 75) that sceptics have good ground for arguing that the social benefits flowing from a large-size cooperative sector are barely such as to justify the requisite expenditure. Considering the nature of Dow's approach, it comes as no surprise that he fails to emphasise the paucity of government support compared to the considerable social benefits of a system of cooperatives-which in our estimation is the crucial point.

\section{Conclusions}

In this paper we have emphasised the idea that progress in the direction of a generalised system of cooperative firms would amount to a considerable improvement over capitalism, but will hardly be made without the effective contribution of intellectuals and political parties. Consistently with our own line of reasoning, Dahl (1989 [98], p. 331) has remarked that both at the national and corporate levels democracy requires favourable circumstances, i.e. conditions which do not lie in the nature of things and will therefore not arise as a matter of course.

Considering the importance that is generally attached to democracy, there are reasons to argue that political 
parties should stop waiting for a worker-controlled firm system to grow in its own right and should make it their task to support its emergence by framing platforms envisaging suitable forms of public intervention. In Ramsay 1983 [99], the struggles for worker control in firms are described as a cyclical, rather than continuous process. In particular, the cyclical attempts of workers to seize factories spanned the years 1917-1921, 1935-1937 and 19681983 (see Visser 1989 [100], pp. 171-176) and were sparked off not only by the political circumstances prevailing from time to time, but also by advancements in economic theory. More than in any other fields, in the area of cooperation a major breakthrough can only be achieved through the combined action of spontaneous evolution, the recommendations of economic theorists and focused political programmes.

\section{References}

[1] Oakeshott, R. (1978) The Case for Workers’ Co-ops. Routledge and Kegan Paul, London.

[2] Cornforth, C., Thomas, A., Lewis, J. and Spear, R. (1988) Developing Successful Worker Cooperatives. Sage, London.

[3] Ellerman, D.P. (1990) The Democratic Worker-Owned Firm. Unwin Hyman, Boston.

[4] Bardhan, P. and Roemer, J.E., Eds. (1993) Market Socialism: The Current Debate. Oxford Economic Press, New York.

[5] Jossa, B. (2005) La teoria economica delle cooperative di produzione e la possibile fine del capitalismo. Giappichelli, Turin.

[6] Jossa, B. (2012) Cooperative Firms as a New Production Mode. Review of Political Economy, 24, 399-416. http://dx.doi.org/10.1080/09538259.2012.701915

[7] Mill, J.S. (1871) Principi di economia politica. III Edit., Ital. transl. UTET, Turin, 1953.

[8] Walras, L. (1990) Etudes d'économie social, Oeuvres économique complètes. Vol. IX, Econonica, Paris.

[9] Gibson-Graham, J.K. (2003) Enabling Ethical Economies: Cooperativism and Class. Critical Sociology, 29, $123-161$. http://dx.doi.org/10.1163/156916303769155788

[10] Nozick, R. (1974) Anarchy, State and Utopia. Basil Blackwell, Oxford.

[11] Jensen, M.C. and Meckling, W.J. (1979) Rights and Production Functions: An Applications to Labor-Managed Firms and Codetermination. The Journal of Business, 52, 469-506. http://dx.doi.org/10.1086/296060

[12] Williamson, O.E. (1985) The Economic Institutions of Capitalism. Free Press, New York.

[13] Mandel, E. (1973) The Debate on Workers’ Control. In: Hunnius, G., Garson, G.D. and Case, J., Eds., Workers’ Control, Vintage Books, New York.

[14] Vanek, J. (1969) Decentralization under Workers’ Management: A Theoretical Appraisal. The American Economic Review, 59, 1006-1014.

[15] Vanek, J. (1970) The General Theory of Labor-Managed Market Economies. Cornell University Press, Ithaca.

[16] Horvat, B. (1975) On the Theory of the Labor-Managed Firm. Reprinted in: Prychitko, D.L. and Vanek, J., Eds. (1996) Producer Cooperatives and Labor-Managed Systems. E. Elgar, Cheltenham.

[17] Jossa, B. and Cuomo, G. (1997) The Economic Theory of Socialism and the Labour-managed Firm. E. Elgar, Cheltenham.

[18] Jossa, B. (2010) A Few Advantages of Cooperative Firms. Studi Economici, 65.

[19] Jossa, B. (2010) Esiste un’alternativa al capitalismo? Manifestolibri, Rome.

[20] Cole, G.C.H. (1953) Attempts at General Union. Macmillan, London.

[21] Hansmann, H. (1996) The Ownership of Enterprise. Belknap Press of the Harvard University Press, Cambridge.

[22] Hamilton, D. (1999) Evolutionary Economics: A Study of Change in Economic Thought. Transaction Publishers, New Brunswick.

[23] Hodgson, G.M. (2003) Darwinism and Institutional Economics. Journal of Economic Issues, 37, 85-97.

[24] De Gregory, T.R. (2003) Muck and Magic or Change and Progress: Vitalism versus Hamiltonian Matter-of-Fact Knowledge. Journal of Economic Issues, 37, 17-33.

[25] Veblen, T.B. (1964) What Veblen Thought. August M. Kelley, New York.

[26] Putterman, L. (1990) Division of Labor and Welfare: An Introduction to Economic Systems. Oxford University Press, Oxford.

[27] Horvat, B. (2000) Social Ownership. 10th Conference of IAFEP, Trient, 6-8 July 2000.

[28] Hodgson, G.M. (1999) Economics and Utopia. Routledge, London.

[29] Miller, E.S. (2003) Evolution and Stasis: The Institutional Economics of David Hamilton. Journal of Economic Issues, 
37, 51-64.

[30] Dugger, W.M. (2003) David Hamilton: A Radical’s Institutionalist. Journal of Economic Issues, 37, 65-73.

[31] Gramsci, A. (1964) Il materialismo storico e la filosofia di Benedetto Croce. Einaudi, Turin.

[32] Commons, J.R. (1924) Legal Foundations of Capitalism. Macmillan, New York.

[33] Commons, J.R. (1934) Institutional Economics; Its Place in Political Economy. Macmillan, New York

[34] Copeland, M.A. (1931) Economic Theory and the Natural Science Point of View. The American Economic Review, 21, 67-79.

[35] Copeland, M.A. (1936) Common’s Institutionalism in Relation to the Problem of Social Evolution and Economic Planning. The Quarterly Journal of Economics, 50, 333-346. http://dx.doi.org/10.2307/1885027

[36] Miller, E.S. (2002) Economics in a Public Interest: Remarks upon Receiving the Veblen-Commons Award. Journal of Economic Issues, 36, 251-260.

[37] Bowles, S. and Gintis, H. (1986) Democracy and Capitalism. Basic Books, New York.

[38] Vanek, J. (1978) La cooperativa di lavoro al crocevia della storia. Ital. Transl in: Hayek, F.A. (1982) Legge, legislazione e libertà. Ital. transl. Milan, Il Saggiatore, 1986.

[39] Hayek, F.A. (1982) Legge, legislazione e libertà. Ital. transl. Milan, Il Saggiatore, 1986.

[40] Leube, K.R. (1989) Social Policy: Hayek and Schmoller Compared. International Journal of Social Economics, 16, 106-116.

[41] Colombatto, E. (2002) Towards a Quasi-Lamarckian Theory of Institutional Change. ICER Working Paper No. 26.

[42] D’Iorio, P. (2013) Ontologia e genealogia nell'estate del 1881. La svolta costruttivista di Nietzsche. Il Ponte, 69, August-September.

[43] Hayek, F.A. (1983) The Rediscovery of Liberty; Personal Recollection. In: Hayek, F.A. (1992) The Fortunes and the Ideal of Freedom. Routledge \& Kegan, London.

[44] Moene, K.O. and Wallerstein, I. (1993) Unions versus Cooperatives. In: Bowles, S., Gintis, H. and Gustafsson, B., Eds., Markets and Democracy: Participation, Accountability and Efficiency, Cambridge University Press, Cambridge.

[45] Kester, G. and Pinaud, H. (1996) Trade Unions and Democratic Participation: a Scenario for the 21 Century. Averbury, Aldershot.

[46] George, D.A.R. (1997) Self-Management and Ideology. Review of Political Economy, 9, 51-62. http://dx.doi.org/10.1080/09538259700000019

[47] Panzieri, R. (1960) Intervento sui temi per il Congresso della CGIL. In: Panzieri, R. (1975) La ripresa del marxismoleninismo in Italia. Sapere Edizioni, Milan.

[48] Schumpeter, J.A. (1954) Capitalismo, socialismo e democrazia. Ital. transl. Edizioni di Comunità, Milan, 1964.

[49] Anderson, P. (1967) The Limits and Possibilities of Trade Union Action. In: Blackburn, R. and Cockburn, A., Eds., The Incompatibles: Trade Unions Militancy and the Consensus, Penguin, London.

[50] Togliatti, P. (1920) Cooperative o schiavitù. Reprinted in: Togliatti, P. (1967) Opere. Ed. by Ernesto Ragionieri. Editori Riuniti, Rome.

[51] Tornquist, D. (1973) Workers’ Management: The Intrinsic Issues. In: Hunnius, G., Garson, G.D. and Case, J., Eds., Workers' Control, Vintage Books, New York.

[52] Salvemini, G. (1993) Movimento socialista e questione meridionale. Ed. by Arfè G. Feltrinelli, Milan.

[53] Braverman, H. (1974) Lavoro e capitale monopolistico. Ital. transl. Einaudi, Turin, 1978.

[54] Adler-Karlsson, G. (1986) Il socialismo “minimale” e il dilemma delle uova. In: AA.VV., Cooperare e competere, Feltrinelli, Milan.

[55] Dubravcic, D. (1970) Labour as an Entrepreneurial Input: An Essay on the Theory of the Producer Cooperative Economy. Economica, 37, 297-310. http://dx.doi.org/10.2307/2551976

[56] Gide, C. (1888) L’avenir de la cooperation. In: Gide, C. (1900) La cooperation: Conferences de propagande. Larousse Forces, Paris.

[57] Labriola, A. (1970) Scritti politici. Ed. by V. Gerratana. Laterza, Bari.

[58] Fabbri, F. (1981) La cooperazione: 1945-1956. In: Ilardi, M. and Accornero, A., Eds., Il Partito Comunista Italiano. Struttura e storia dell'organizzazione. 1921/1979, Annali della Fondazione Giangiacomo Feltrinelli, Milan.

[59] Putterman, L. (1984) On Some Explanations of Why Capital Hires Labor. Economic Inquiry, 22, 171-187. http://dx.doi.org/10.1111/j.1465-7295.1984.tb00677.x

[60] Hodgson, G.M. (1993) Transaction Costs and the Evolution of the Firm. In: Pitelis, C., Ed., Transactions Costs, Mar- 
kets and Hierarchies, Blackwell, Oxford.

[61] Gunn, C. (2000) Markets against Economic Democracy. Review of Radical Political Economics, 32, 448-460. http://dx.doi.org/10.1177/048661340003200310

[62] Artur, W.B. (1989) Competing Technologies, Increasing Returns, and Lock-In by Historical Events. Economic Journal, 99, 116-131. http://dx.doi.org/10.2307/2234208

[63] North, D. (1990) Institutions, Institutional Change and Economic Performance. Cambridge University Press, Cambridge.

[64] Pagano, U. (1991) Property Rights, Asset Specificity, and the Division of Labour under Alternative Capitalist Relations. Cambridge Journal of Economics, 15, 315-342.

[65] Pagano, U. (1991) Imprese, tecnologia e diritti di proprietà. In: Artoni, R., Ed. (1981) Teoria economica e analisi delle istituzioni. Il Mulino, Bologna.

[66] Vanek, J. (1971) Some Fundamental Considerations on Financing and the Form of Ownership under Labor Management. Reprinted in: Vanek, J. (1977) The Labor Managed Economy: Essays. By J. Vanek. Cornell University Press, Ithaca.

[67] Galgano, P. (1974) Le istituzioni dell'economia capitalistica. Zanichelli, Bologna.

[68] Marx, K. and Engels, F. (1845-1846) L’ideologia tedesca. Ital. transl. Editori Riuniti, Rome, 1969.

[69] Perotin, V. (2006) Entry, Exit, and the Business Cycle: Are Cooperatives Different? Journal of Comparative Economics, 34, 295-316. http://dx.doi.org/10.1016/j.jce.2006.03.002

[70] Veblen, T.B. (1899) The Theory of the Leisure Class. Reprint August M. Kelley, New York, 1965.

[71] Ellerman, D.P. (1992) Property and Contract in Economics. Blackwell, Oxford.

[72] Bowles, S. and Gintis, H. (1993) Post-Walrasian Political Economy. In: Bowles, S., Gintis, H. and Gustafsson B., Eds., Markets and Democracy: Participation, Accountability and Efficiency, Cambridge University Press, Cambridge.

[73] Panebianco, A. (2004) Il potere, lo stato, la libertà. Il Mulino, Bologna.

[74] Weingast, B.R. and Marshall, W.J. (1988) The Industrial Organization of Congress; or, Why Legislatures, Like Firms, Are Not Organized as Markets. Journal of Political Economy, 96, 132-163. http://dx.doi.org/10.1086/261528

[75] Kollock, P. (1998) Transforming Social Dilemmas: Group Identity and Cooperation. In: Danielson, P., Ed., Modelling Rationality, Morality and Evolution, Oxford University Press, Oxford.

[76] Huberman, B.A. and Glance, N.S. (1998) Belief and Cooperation. In: Danielson, P., Ed., Modelling Rationality, Morality and Evolution, Oxford University Press, Oxford.

[77] Battilani, P. and Bertagnoni, G., Eds. (2007) Competizione e valorizzazione del lavoro. La rete cooperativa del Consorzio nazionale dei servizi. Il Mulino, Bologna.

[78] Jossa, B. (2014) A System of Cooperative Firms as a New Mode of Production. Routledge, London.

[79] Einaudi, L. (1920) Il significato del controllo operaio. In: Einaudi, L. (1966) Cronache economiche e politiche di un trentennio. Vol. V, 1919-1920, Einaudi, Turin.

[80] Touraine, A. (2004) La globalizzazione e la fine del sociale. Ital. transl. Il Saggiatore, Milan.

[81] Ben-Ner, A. (1987) Producer Cooperatives: Why Do They Exist in Market Economies? In: Powel, W., Ed., The Nonprofit Sector: A Research Handbook, Yale University, New Haven.

[82] Hart, O. and Moore, J. (1990) Property Rights and the Nature of the Firm. Journal of Political Economy, 98, 11191158. http://dx.doi.org/10.1086/261729

[83] Steinherr, A. and Vanek, J. (1976) Labour-Managed Firms and Imperfect Competition. Economic Journal, 86, 339-341. http://dx.doi.org/10.2307/2230755

[84] Bernstein, E. (1899) Socialismo e socialdemocrazia. Ital. transl. Laterza, Bari, 1968.

[85] Meade, J.E. (1972) The Theory of Labour-Managed Firms and of Profit Sharing. Economic Journal, 82, 402-428. http://dx.doi.org/10.2307/2229945

[86] Cornforth, C. (1989) Worker Cooperatives in U.K.: Temporary Phenomenon or Growing Trend? In: Lammers, C.J. and Széll, G., Eds., International Handbook of Participation in Organization, Vol. I, Organizational Democracy: Taking Stock, Oxford University Press, Oxford.

[87] Obradovic, J. and Dunn, W., Eds. (1978) Workers’ Self Management and Organizational Power in Yugoslavia. Centre for International Studies, University of Pittsburgh, Pittsburgh.

[88] Kalecki, M. (1937) The Principle of Increasing Risk. Economica, 3, 440-447. http://dx.doi.org/10.2307/2626879

[89] Drèze, J.H. (1989) Labour-Management, Contracts and Capital Markets. A General Equilibrium Approach. Basil 
Blackwell, Oxford.

[90] Drèze, J.H. (1993) Self-Management and Economic Theory: Efficiency, Funding and Employment. In: Bardhan, P. and Roemer, J.E., Eds., Market Socialism: The Current Debate, Oxford Economic Press, New York.

[91] Putterman, L., Roemer, J.E. and Silvestre, J. (1998) Does Egalitarianism Have a Future? Journal of Economic Literature, 36, 861-902.

[92] Pittatore, S. and Turati, G. (2000) A Map of Property Rights in Italy and the Case of Cooperatives: An Empirical Analysis of Hansmann's Theory. Economic Analysis, 3, 23-48. http://dx.doi.org/10.1080/13668090050004251

[93] Webb, S. and Webb, B. (1921) A Constitution for the Socialist Commonwealth of Great Britain. Longmans, London.

[94] Webb, S. and Webb, B. (1923) The Decay of Capitalistic Civilization. Allen \& Unwin, London.

[95] Ben-Ner, A. (1984) On the Stability of the Cooperative Type of Organization. Journal of Comparative Economics, 8, 247-260. http://dx.doi.org/10.1016/0147-5967(84)90055-6

[96] Ben-Ner, A. (1988) The Life Cycle of Worker-Owner Firms in Market Economies: A Theoretical Analysis. Journal of Economic Behavior and Organization, 10, 287-313. http://dx.doi.org/10.1016/0167-2681(88)90052-2

[97] Dow, G. (2003) Governing the Firm; Workers’ Control in Theory and Practice. Cambridge University Press, Cambridge.

[98] Dahl, R.A. (1989) Democracy and Its Critics. Yale University Press, Yale.

[99] Ramsey, H. (1983) Evolution or Cycle? Worker Participation in the 1970s. In: Crouch, C. and Heller, F., Eds., International Yearbook of Organizational Democracy, Wiley, Chichester.

[100] Visser, J.C. (1989) Factory Occupation and Industrial Democracy. In: Lammers, C.J. and Széll, G., Eds., International Handbook of Participation in Organization, Vol. 1, Organizational Democracy: Taking Stock, Oxford University Press, Oxford. 